\title{
Slower Fibrosis Progression Among Liver Transplant Recipients With Sustained Virological Response After Hepatitis C Treatment
}

\author{
Shahid Habib ${ }^{\mathrm{a}, \mathrm{e}}$, Edward Meister ${ }^{\mathrm{b}}$, Sana Habib ${ }^{\mathrm{a}}$, Traci Murakamia ${ }^{\mathrm{a}}$, Courtney Walker ${ }^{\mathrm{a}}$, \\ Abbas Rana ${ }^{\mathrm{c}}$, Obaid S. Shaikh ${ }^{\mathrm{d}}$
}

\begin{abstract}
Background: The natural course of hepatic fibrosis in HCV allograft recipients with sustained virological response (SVR) after anti-HCV therapy remains debatable. The aim of this study was to examine the progression of fibrosis in a cohort of patients who achieved SVR compared with those without treatment.
\end{abstract}

Methods: The 167 patients who met the inclusion and exclusion criteria were chosen from a transplant database. All patients were required to have histological evidence of recurrent $\mathrm{HCV}$ infection postliver transplantation and a follow-up biopsy. The 140 of these patients had received anti-viral therapy. Twenty-seven patients were identified as controls and were matched with the treatment group in all respects. The patients were categorized into four groups based on treatment response: 1) no treatment (control) $(\mathrm{n}=27) ; 2)$ non-responders $(\mathrm{n}=$ $81) ; 3)$ relapsers $(\mathrm{n}=32)$; and 4$) \mathrm{SVR}(\mathrm{n}=27)$. The endpoint was the stage of fibrosis on the follow-up liver biopsy.

Results: The treated and untreated groups were similar in clinical characteristics at the time of transplantation and prior to the initiation of treatment. The $72 \%$ of the cohort showed a fibrosis progression of $\geq 1$ stage; this change did not significantly differ between the patient groups. Nonetheless, the fibrosis progression rate was the highest in the untreated group and lowest in the patients who achieved SVR. A coefficient of determination was used. Improvements in fibrosis scores were found with greater treatment duration. These improvements were most evident with the achievement of SVR.

Conclusions: In conclusion, SVR after anti-viral therapy for recurrent hepatitis $\mathrm{C}$ infection post-transplantation was associated with

Manuscript accepted for publication September 24, 2015

aLiver Institute, Department of Internal Medicine, Divisions of Gastroenterology, Hepatology and Transplantation, University of Arizona, AZ, USA

bDepartment of Medicine, University of Arizona, AZ, USA

'Division of Transplantation Surgery, Department of Surgery, Baylor College of Medicine, TX, USA

${ }^{d}$ Division of Transplantation Surgery and Thomas E. Starzl Transplantation Institute, University of Pittsburgh School of Medicine, Pittsburgh, PA, USA

${ }^{e}$ Corresponding Author: Shahid Habib, Liver Institute PLLC, 2830 N. Swan Rd., Tucson, AZ 85712, USA. Email: shabib@liverinstitutepllc.org

doi: http://dx.doi.org/10.14740/gr686w slower fibrosis progression and significantly improved graft survival.

Keywords: Modified Ishak-Knodell activity index; Retrospective study; Liver allograft; Fibrosis progression; Patient and graft survival

\section{Introduction}

Chronic hepatitis $\mathrm{C}$ virus (HCV) is the leading indication for liver transplantation in the United States. Graft reinfection with hepatitis $\mathrm{C}$ occurs universally after liver transplantation and is a significant factor in graft loss, re-transplantation and increased mortality. In the liver allograft, the course of HCV infection is often aggressive and results in lower rates of graft and patient survival compared with patients without HCV infection [1]. Up to $28 \%$ of patients develop cirrhosis within 5 years of transplantation [2]. Additionally, severe cholestatic hepatitis develops in approximately $10 \%$ of $\mathrm{HCV}$-infected graft recipients, usually within 6 months of transplantation, and results in graft loss if left untreated [3, 4]. Treatment efficacy with standard or pegylated interferon and ribavirin is also suboptimal compared with immunocompetent individuals $[5,6]$, and the efficacy of direct antiviral agents has not been well studied in liver allograft recipients. However, preliminary results are very promising $[7,8]$.

In pre-transplant $\mathrm{HCV}$ cirrhotic patients, achieving sustained viral response (SVR) after anti-HCV treatment has clearly resulted in fibrosis regression [9-11]. However, the effect of SVR on fibrosis progression is not well studied in post-liver transplantation HCV patients. We performed PubMed (MeSH) and other data searches and identified 10 studies that investigated the effects of SVR on fibrosis progression [12-21]. Eight out of 10 studies are from Europe, and two are from the USA. Not all of the studies were designed to investigate changes in fibrosis, which was analyzed in a subgroup of the study cohort. All studies showed improvements in necroinflammatory score; however, fibrosis improvement was not universal, and there was variability in how the fibrosis data was reported [12-21] (Table 1).

One study found that the grade of inflammation and fibrosis stage improved from baseline histology in the majority of $\mathrm{HCV}$ patients treated with interferon and ribavirin post-transplantation [16]. Another study found that interferon treatment of re- 
Table 1. Literature Review [12-21]

\begin{tabular}{|c|c|c|c|c|c|c|}
\hline Author & Year & Country & $\mathbf{N}$ & Study design & $\mathbf{C G}$ & FU \\
\hline Tame et al [15] & 2013 & Italy & $35^{*}$ & Prospective & $\mathrm{N}$ & 40 \\
\hline Belli et al [12] & 2012 & Italy & $69 *$ & RCT & $\mathrm{Y}$ & 36 \\
\hline Bizollon et al [13] & 2007 & France & $25 *$ & Prospective & $\mathrm{Y}$ & 6 \\
\hline Oton et al [17] & 2006 & Spain & $15^{*}$ & Retrospective & $\mathrm{N}$ & 6 \\
\hline Barenguer et al [19] & 2009 & Spain & $47 *$ & Retrospective & $\mathrm{N}$ & 12 \\
\hline Stravitz et al [21] & 2004 & USA & 23 & Retrospective & $\mathrm{N}$ & 23 \\
\hline Abdelmalek et al [20] & 2004 & USA & $26^{*}$ & Retrospective & $\mathrm{N}$ & $24-60$ \\
\hline Bahra et al [14] & 2007 & Germany & 28 & Prospective & $\mathrm{N}$ & 36 \\
\hline
\end{tabular}

\begin{tabular}{|c|c|c|c|c|}
\hline Pre-treatment fibrosis & Effect on fibrosis: SVR & Effect on fibrosis: NR & Effect on fibrosis: control & P value \\
\hline Metavir 2/4 & $\begin{array}{l}(\mathrm{n}=9) \\
32 \% \text { improved, } 68 \% \text { unchanged, } \\
0 \% \text { worsened }\end{array}$ & $\begin{array}{l}(\mathrm{n}=19) \\
38 \% \text { improved, } 66 \% \text { unchanged, } \\
16 \% \text { worsened }\end{array}$ & $\begin{array}{l}(\mathrm{n}=7) \\
70 \% \text { improved, } 50 \% \\
\text { unchanged, } 50 \% \text { worsened }\end{array}$ & 0.05 \\
\hline Ishaq-Knodell $\leq 3 / 6$ & $\begin{array}{l}(\mathrm{n}=15) \\
20 \% \text { worsening }\end{array}$ & $\begin{array}{l}(\mathrm{n}=21) \\
47.6 \% \text { worsening }\end{array}$ & $\begin{array}{l}(\mathrm{n}=36) \\
50 \% \text { worsening }\end{array}$ & 0.04 \\
\hline Metavir 2/4 & $\begin{array}{l}(\mathrm{n}=18) \\
50 \% \text { improved, } 50 \% \text { stable, } 0 \% \\
\text { worse }\end{array}$ & $\begin{array}{l}(\mathrm{n}=36) \\
6 \% \text { improved, } 36 \% \\
\text { stable, } 58 \% \text { worse }\end{array}$ & $\begin{array}{l}(\mathrm{n}=27) \\
4 \% \text { improved, } 26 \% \\
\text { stable, } 70 \% \text { worse }\end{array}$ & 0.009 \\
\hline Unknown & $\begin{array}{l}(\mathrm{n}=8) \\
100 \% \text { improved, } 0 \% \text { stable, } 0 \% \\
\text { worse }\end{array}$ & $\begin{array}{l}(\mathrm{n}=17) \\
65 \% \text { improved, } 35 \% \\
\text { stable, } 0 \% \text { worse }\end{array}$ & $\begin{array}{l}(\mathrm{n}=21) \\
5 \% \text { improved, } 19 \% \text { stable, } \\
76 \% \text { worse }\end{array}$ & $\begin{array}{l}\text { Significant; } \\
\text { P value not } \\
\text { presented }\end{array}$ \\
\hline Ishaq-Knodell $\geq 1 / 6$ & $\begin{array}{l}(\mathrm{n}=7) \\
\text { mean score pre-treatment: } 2.4 / 6 \\
\text { mean score post-treatment: } 2.6 / 6\end{array}$ & $\begin{array}{l}(\mathrm{n}=8) \\
\text { mean score pre-treatment: } 2.7 / 6 \text {, } \\
\text { mean score post-treatment: } 3.7 / 6\end{array}$ & & NS \\
\hline \multirow[t]{2}{*}{ HAI fibrosis stage $0-4$} & $\begin{array}{l}\text { No change and } \\
\text { improvement } 46 \%\end{array}$ & No change and improvement $44 \%$ & & NS \\
\hline & $\begin{array}{l}(\mathrm{n}=11) \\
\text { mean score pre-treatment: } 1.9 / 4, \\
\text { mean score post-treatment: } 1.5 / 4\end{array}$ & $\begin{array}{l}(\mathrm{n}=12) \\
\text { mean score pre-treatment: } 2.5 / 4 \text {, } \\
\text { mean score post-treatment: } 2.7 / 4\end{array}$ & & NS \\
\hline Not known & $\begin{array}{l}\text { At year } 2 \mathrm{FU}, 27 \% \text { improved, } \\
38 \% \text { unchanged, } 35 \% \text { worsened, } \\
\text { At year } 3-5 \mathrm{FU}, 67 \% \text { improved, } \\
13 \% \text { unchanged, } 20 \% \text { worsened. }\end{array}$ & & & 0.05 \\
\hline
\end{tabular}

$\mathrm{N}$ : number of patients; NS: not significant; *: number of patients evaluated histologically; CG: control group; NR: non-responders; SVR: sustained virological response; FU: follow-up. 
current hepatitis $\mathrm{C}$ did not consistently improve histology after virological response and may even increase the risk of allograft rejection [17]. There is significant heterogeneity between studies, and only a minority of patients undergo liver biopsy both prior to and after antiviral therapy. Patients who achieved SVR post-transplantation have graft and patient survival rates similar to those without HCV infection [22-27]. Nevertheless, patients who remain virological are at risk for progressive disease [2224]. In summary, there is no conclusive evidence indicating that achieving SVR with anti-HCV therapy post-transplantation results in fibrosis regression and the question remains debated.

To clarify whether treating hepatitis $\mathrm{C}$ results in any level of fibrosis regression, we examined the effect of antiviral therapy for $\mathrm{HCV}$ on the progression of fibrosis in a large cohort of patients who received liver transplants for hepatitis $\mathrm{C}$ cirrhosis. We compared patients who received antiviral therapy (an interferonbased regimen that included protease inhibitors) with those who were not treated (control). Liver fibrosis progression rates were analyzed in relation to virus clearance post-treatment. To our knowledge, this is the largest cohort studied in this regard.

\section{Materials and Methods}

\section{Study population}

The protocol was approved by the institutional review board at the Thomas E. Starzl Transplantation Institute at the University of Pittsburg. Adult patients aged 18 years and older who were transplanted for HCV cirrhosis were included for retrospective analysis. The patients were identified using an electronic database that prospectively enrolled liver transplant candidates and recipients. The diagnosis of hepatitis $\mathrm{C}$ was based on a positive anti-HCV test and HCV RNA. All patients were required to have histological evidence of recurrence prior to the initiation of therapy (baseline biopsy) and have had a follow-up biopsy at least 6 months post-treatment.

\section{Anti-HCV therapy}

Patients who were identified to have abnormal aminotransferases or cholestatic hepatitis were suspected of having recurrent $\mathrm{HCV}$ infection after the exclusion of other etiologies. All patients were considered for treatment once histologic recurrence was established. Anti-HCV therapy included unmodified interferon- $\alpha 2 b$ (INTRON $\left.{ }^{\circledR} A\right)$, pegylated interferon- $\alpha 2 b$ (PegIntron $^{\circledR}$ ) and pegylated interferon- $\alpha 2 \mathrm{a}$ (Pegasys $\left.{ }^{\circledR}\right)$, ribavirin and protease inhibitors (telaprevir and boceprevir). Treatment length varied according to side effects, tolerance and response to treatment. Genotype 2 and 3 patients received treatment for 6 months. In patients with other genotypes, treatment was planned for at least 48 weeks. However, in some patients, treatment was discontinued prematurely because of significant side effects and/or no response to treatment. In others, treatment was prolonged per response-guided therapy. The patients were considered to have SVR if HCV RNA was negative at 6 months after the completion of treatment. The treatment group was categorized based on response to treatment: SVR, relapsers and non-responders.

\section{Control group}

The control group comprised patients who were determined to have histological recurrent $\mathrm{HCV}$ infection and were considered for treatment but refused to undergo treatment. They also have had follow-up biopsies. These patients were matched with the treatment group in all respects.

\section{Histological assessment}

All allograft biopsies were included in the analysis. The biopsies were read routinely by one of the liver pathologists at our institution and subsequently reviewed by another pathologist. The severity of inflammation and fibrosis was graded and staged according to the modified Ishak-Knodell activity index (MHAI), and the severity of allograft rejection was scored according to the Banff schema [28, 29].

\section{Study endpoints}

The primary endpoint of the study was fibrosis progression rate (stage of fibrosis on the last follow-up liver biopsy) in the hepatic allograft.

\section{Statistical analysis}

Chi-square and ANOVA one-way analysis were used to compare baseline clinical features for the dichotomous and continuous variables, respectively. A Kaplan-Meier analysis with a log-rank test was performed for survival estimates. The log delta time was calculated to minimize the effect of variable duration between the two biopsies. An R-squared regression analysis was used to measure the percentage of the total variation in the change of fibrosis as explained by the regression model. A non-linear cubic fit model was used to display a comparison between the untreated groups vs. the treatment groups in terms of the achievement of SVR. As the R-squared value increases, the observed values are more closely fit to the regression model. This would indicate a favorable and more impressive regression score. A P value of $\leq 0.05$ was considered to be statistically significant. A statistical software package was used (SPSS 22 for Windows 2008; SPSS Inc., Chicago, IL, USA).

\section{Results}

\section{Study cohort transplantation course}

A total of 167 patients met the inclusion and exclusion criteria and underwent the final analysis. The study cohort was catego- 
Table 2. Clinical Characteristics of Patients Prior to Anti-HCV Therapy

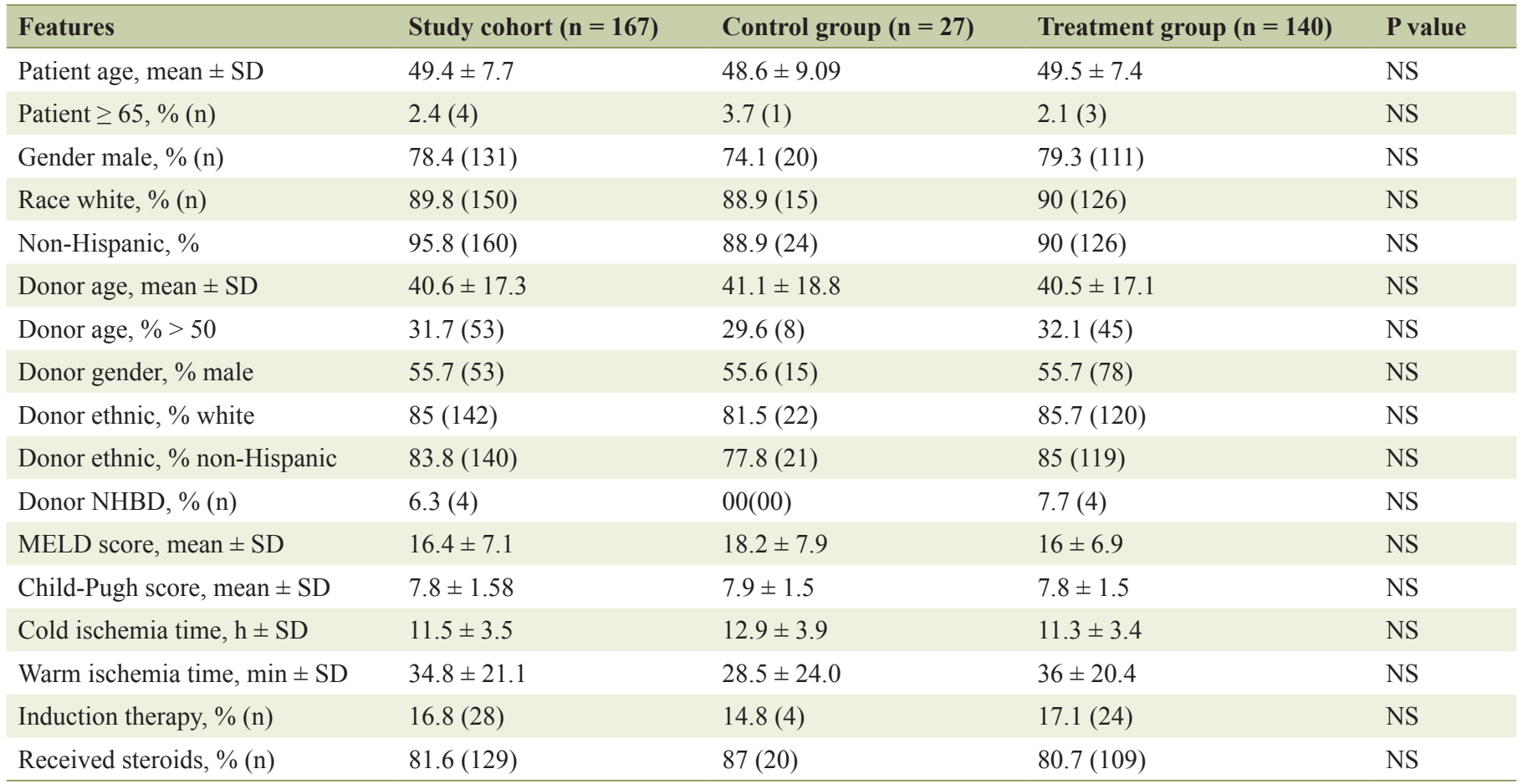

n: number of patients; NHBD: non-heart beating donor; MELD: model for end-stage liver disease; CTP: Child-Turcotte-Pugh.

rized into two main groups: a no treatment group $(n=27)$ and a treatment group $(n=140)$. The treatment group consisted of three subgroups: 1) non-responders $(\mathrm{n}=81)$; 2) responder relapsers $(\mathrm{n}=32)$; and 3$)$ SVR $(\mathrm{n}=27)$. The recipient, donor and transplant variables of the overall study cohort were evaluated (Table 1). The majority of transplant recipients were males $(78 \%)$ with a mean age of 49 years, a mean BMI of 28.30 and the majority of recipients were white (90\%). Of the participants, $96 \%$ were non-Hispanic. The $2 \%$ of the recipients were older than 65 years.

The demographic, recipient, donor and immunosuppression features were similar between the control and treatment groups (Table 2). At the time of transplantation, the severity of liver disease as indicated by the model for end-stage liver disease (MELD) scores and Child-Pugh scores were similar between the two groups. Both groups were also similar regarding post-transplant course and immunosuppression management. The majority of patients received tacrolimus-based immunosuppressive regimens, and some received induction immunosuppression with either anti-thymocyte globulin (Thymoglobulin ${ }^{\circledR}$ ) or alemtuzumab $\left(\right.$ Campath $\left.^{\circledR}\right)$. The use of either intravenous or oral corticosteroids was similar between the two groups. Steroid bolus use for acute rejection episodes was also similar in both groups.

\section{Anti-HCV treatment course}

All patients developed recurrent $\mathrm{HCV}$ infection within 6 months of transplantation. They manifested with abnor- mal aminotransferases, and the mean aspartate transaminase (AST) and alanine aminotransferase (ALT) were 91 and 100 $\mathrm{IU} / \mathrm{mL}$, respectively. The majority of patients were non-cholestatic with a mean bilirubin of $1.2 \mathrm{mg} / \mathrm{dL}$ and alkaline phosphatase of $190 \mathrm{IU} / \mathrm{mL}$. Pre-treatment biopsy was performed at a mean interval of 335 days (11 months) with $\mathrm{SD} \pm 410$ days from the date of transplantation. Histopathology showed an Ishak-Knodell MHAI grade of 4.9/18 with $\mathrm{SD} \pm 2.6$ and fibrosis stage of $1.3 / 6$ with $\mathrm{SD} \pm 1.4$. Treatment was initiated at a mean interval of 375 days (12.3 months) with an SD of \pm 427 days. The mean bilirubin and creatinine at initiation of treatment were $1.8 \mathrm{mg} / \mathrm{dL}$ and $1.2 \mathrm{mg} / \mathrm{dL}$, respectively. Treatments continued per the guidelines: 24 weeks for genotype 2 and 3 and $\geq 48$ weeks for genotype 1 . Treatments were prematurely discontinued for adverse events. Some patients received response-guided therapy, especially with protease inhibitors. The control group was carefully selected to match the treatment group regarding pre-treatment characteristics such as general features, biochemistry, time of biopsy and histopathology (Table 3). The majority of the treatment group (69\%) received treatment for $\geq 48$ weeks, and $21 \%$ received $24-47$ weeks of treatment. A minority of patients received treatments for up to 24 weeks. The rapid virological response and early virological response could not be precisely determined due to the retrospective nature of the study; however, $42 \%$ of the treatment group responded to the therapy by achieving an HCV-negative status during treatment. The $16 \%$ of the treatment group was confirmed to have SVR status. The mean duration of the follow-up biopsy was 1.5 years after the completion of treatment. The mean interval between the two biopsies 
Table 3. Anti-HCV Treatment Course

\begin{tabular}{|c|c|c|c|c|c|}
\hline \multirow{2}{*}{ Clinical features } & \multicolumn{2}{|c|}{ Control $(n=27)$} & \multicolumn{2}{|c|}{ Treatment $(n=140)$} & \multirow{2}{*}{ P value } \\
\hline & Mean & SD & Mean & SD & \\
\hline Bilirubin pre-treatment, mg/dL & 0.91 & 0.61 & 1.29 & 1.92 & NS \\
\hline Bilirubin at initiation, $\mathrm{mg} / \mathrm{dL}$ & 2.86 & 6.07 & 1.61 & 3.47 & NS \\
\hline Bilirubin at follow-up, $\mathrm{mg} / \mathrm{dL}$ & 5.49 & 9.14 & 3.77 & 8.53 & NS \\
\hline ALT pre-treatment, IU/dL & 121.56 & 122.84 & 96.89 & 103.40 & NS \\
\hline AST pre-treatment, IU/dL & 99.11 & 115.61 & 90.09 & 130.42 & NS \\
\hline AST/ALT pre-treatment & 0.89 & 0.51 & 0.92 & 0.42 & NS \\
\hline ALP pre-treatment, IU/dL & 275.73 & 311.36 & 171.11 & 190.02 & NS \\
\hline Cholestasis index & 2.29 & 2.46 & 2.21 & 1.95 & NS \\
\hline Creatinine pre-treatment, $\mathrm{mg} / \mathrm{dL}$ & 1.35 & 0.51 & 1.26 & 0.42 & NS \\
\hline Time from transplant to pre-treatment biopsy, years & 0.99 & 1.46 & 0.90 & 1.05 & NS \\
\hline MHAI grade 0 - 18 pre-treatment & 5.20 & 1.86 & 4.93 & 2.78 & NS \\
\hline Fibrosis stage 0 - 6 pre-treatment & 1.11 & 1.31 & 1.34 & 1.46 & NS \\
\hline Time from transplant to treatment, years & & & 0.98 & 1.06 & NS \\
\hline Treatment duration, years & & & 1.62 & 1.16 & NS \\
\hline Time from transplant to follow-up biopsy, years & 3.29 & 2.31 & 3.97 & 2.89 & NS \\
\hline
\end{tabular}

SD: standard deviation; ALT; alanine aminotransferase; AST: aspartate aminotransferase; ALP: alkaline phosphatase; MHAI: modified histologic activity index.

was 2.9 years.

\section{Fibrosis analysis}

We analyzed fibrosis progression in the three treatment response subgroups (SVR, relapsers and non-responders) and compared them with the control group. The control group was similar to the treatment groups regarding the timing of biopsies and pre-treatment histologic disease activity (Table 4 ). There was $\geq 1$ stage progression of fibrosis in $72 \%$ of the study cohort with a similar progression in each group without achieving statistical significance (Fig. 1). The mean change in fibrosis score among all treatment subgroups and the control group was statistically similar; however, there was a trend toward a smaller magnitude of change in the control group to SVR $(\mathrm{P}=0.08)$. Potential correlations regarding the time interval between the biopsies and the change in fibrosis score (time-dependent fibrosis change) were assessed in all study groups. The fibrosis progression rate in all four groups was highest in the control group (1.02 stages per year) and lowest in patients who achieved SVR ( 0.45 stages per year); nevertheless, there was a trend toward slower progression in patients with SVR $(P=0.08)$. Using a non-linear cubic model, there was an improvement in fibrosis scores that was most strongly demonstrated in the patients who achieved SVR as opposed to the patients who achieved relapse or have not responded (Fig. 2). Overall, a trend of slower progression of fibrosis over time

Table 4. Fibrosis Analysis

\begin{tabular}{|c|c|c|c|c|c|}
\hline & Control group & Non-responders & Relapsers & SVR & P value \\
\hline Time interval between LT and initiation of treatment, years & & 0.89 & 1.17 & 1.01 & NS \\
\hline Time interval between LT and first liver biopsy, years & 1.03 & 0.81 & 1.06 & 0.96 & NS \\
\hline Time interval between first and second liver biopsy, years & 2.37 & 3.32 & 2.40 & 3.00 & Ns \\
\hline Mean fibrosis change between two biopsies & 2.04 & 2.11 & 1.57 & 1.37 & 0.08 \\
\hline Regression, \% (n) & $7.4(2)$ & $7.4(6)$ & $6.2(2)$ & $11.1(3)$ & \\
\hline No change, $\%$ (n) & $18.5(5)$ & $22.2(18)$ & $18.8(6)$ & $18.5(5)$ & \\
\hline Progression, \% (n) & $74.1(20)$ & $70.4(57)$ & $75(24)$ & 70.4 (19) & \\
\hline
\end{tabular}

LT: liver transplantation. 


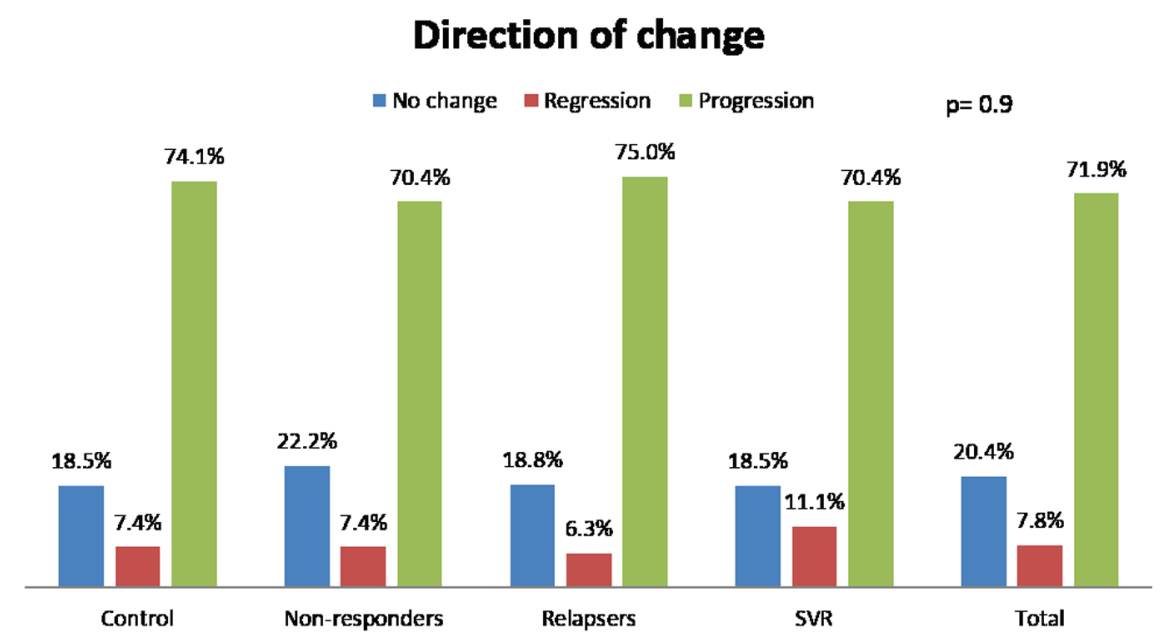

Figure 1. Change of fibrosis in patients. SVR: sustained virological response.
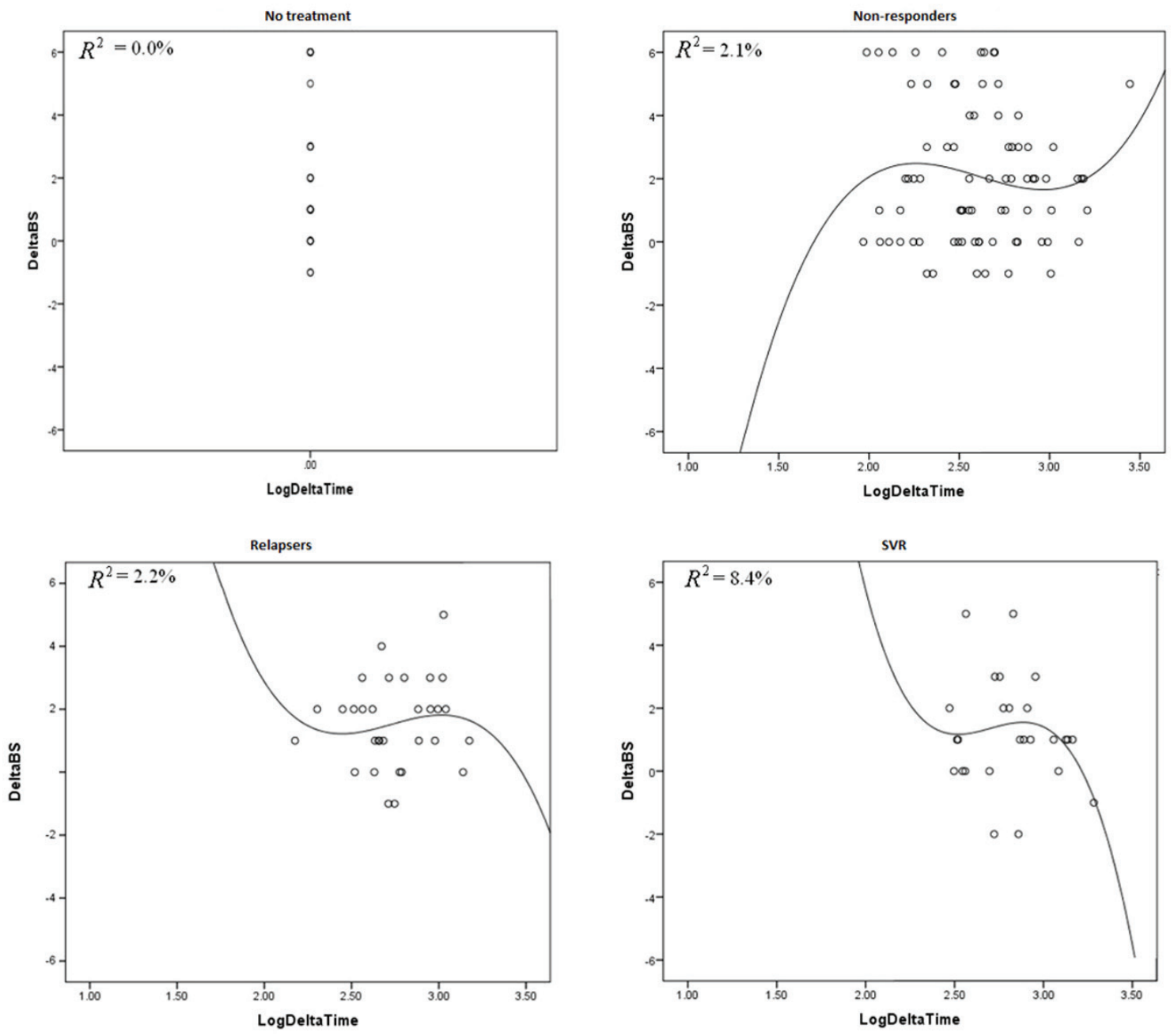

Figure 2. These graphs plot $R^{2}$ against delta log time in all treatment groups and control group. 
Plot of R-Sq by Treatment Type

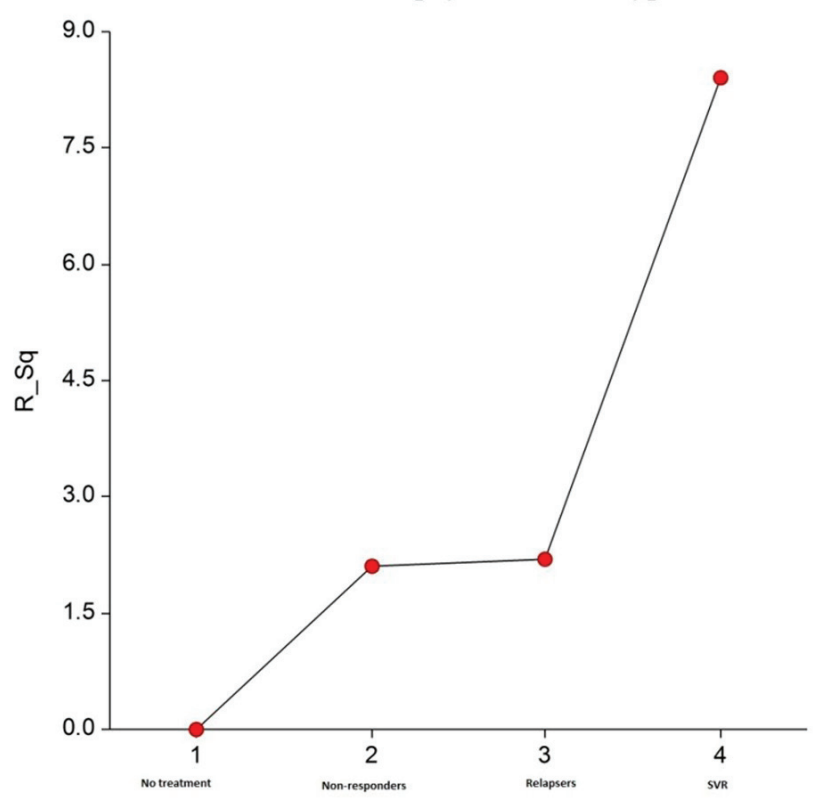

Figure 3. Plots $R^{2}$ by treatment type. This shows increasing trend in percentage of $\mathrm{R}^{2}$ for a non-linear cubic model fit from "no treatment" to "SVR treatment". This indicates favorable improvement in time dependent fibrosis scores, and this was most evident with SVR. was observed in patients who achieved SVR (Fig. 3).

\section{Survival analysis}

Graft survival analysis showed improved survival in patients with SVR compared with those without (Fig. 4). The risk of mortality was higher if the patient remained untreated or did not respond to treatment (HR: control 7.6 $(\mathrm{P}=0.008)$, NR 4.7 $(\mathrm{P}=0.034)$, relapsers $3.7(\mathrm{P}=1.05))$.

\section{Conclusions}

The rigors of a well-designed, controlled study are difficult to apply to transplanted patients primarily due to the concurrent hematologic and renal side effects of immunosuppression. We initially designed a prospective clinical trial to study anti-HCV therapy in liver transplant recipients; this prospective trial was ended because of enrollment failure [30]. Several uncontrolled studies have examined the efficacy of unmodified interferon and ribavirin monotherapies, as well as that of an interferon and ribavirin combination in patients with histological recurrent $\mathrm{HCV}$ infection [5, 31-40]. It remains unknown whether achieving SVR with anti-HCV treatment can stabilize fibrosis progression.

We performed a data search and analyzed the results of all of the studies evaluating the effect of SVR on hepatic fibrosis (Table 1). Among them, two were randomized control trials

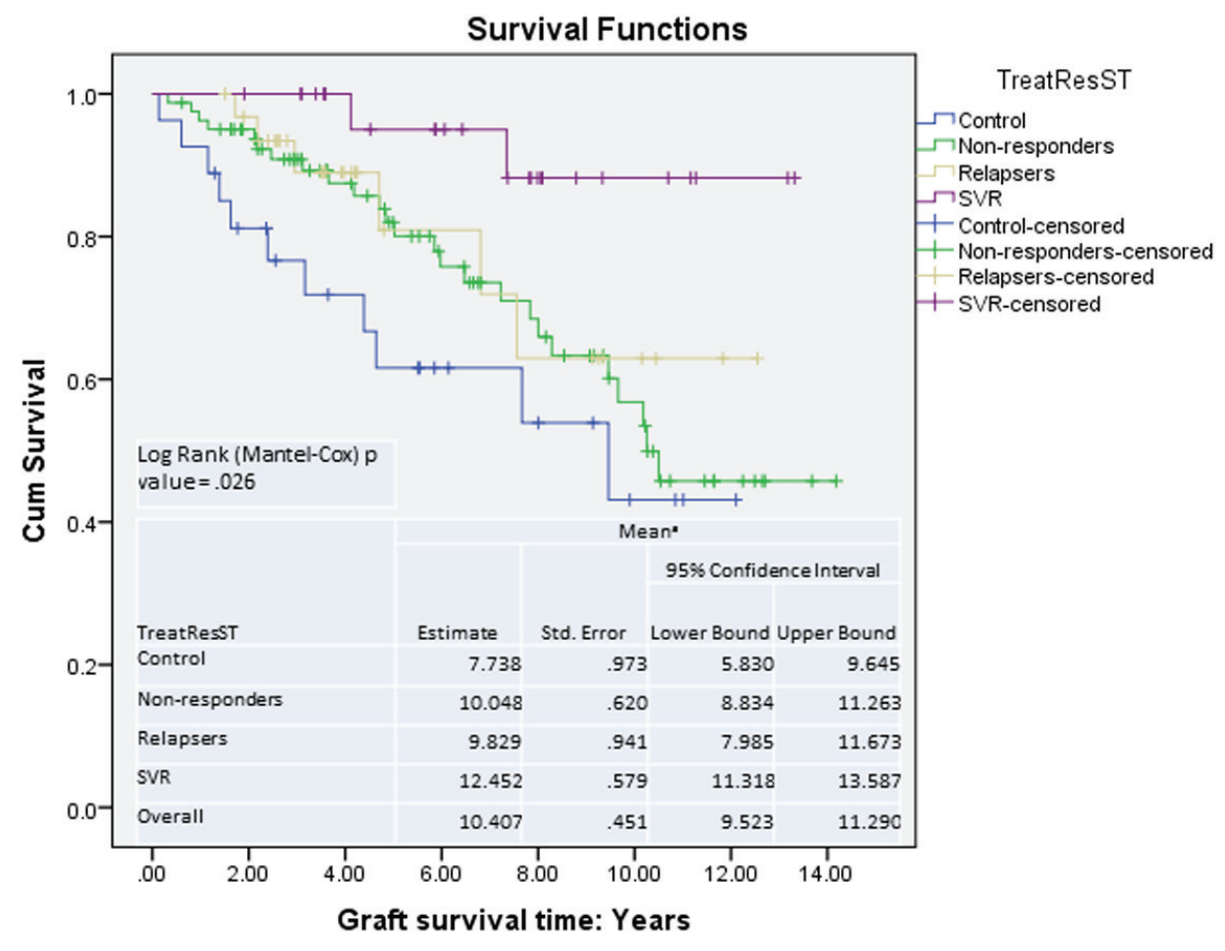

Figure 4. Graft survival: Kaplan-Meier survival curves. 
$[12,16]$, and both showed a significant regression of fibrosis over a period of 6 months to 2 years following the completion of treatment; however, one study did not differentiate between stable and improved fibrosis. Other studies from Europe evaluated only a small number of patients showing similar patterns of fibrosis progression in SVR, non-responders and control groups. Two case control studies showed improvements in histology; however, these were not compared with non-responders or control groups $[14,20]$.

Our study evaluated a large cohort of post-transplant HCV patients and did not demonstrate significant histologic regression in patients who achieved SVR with anti-HCV therapy compared with other groups (including controls). Treating recurrent hepatitis $\mathrm{C}$ in liver transplant recipients appears to be beneficial because antiviral therapy is associated with a slower progression of fibrosis with SVR status. Our study clearly confirmed improved graft survival, as previously published. Our study did not confirm fibrosis regression, as was shown in two previously published clinical studies $[12,16]$. Our results are consistent with those of other studies and confirmed slower progression with SVR status. Clinically, this finding is important and stresses the need for prompt treatment. All patients should be offered anti-HCV treatment, especially in the era of direct-acting antivirals (DAAs).

Significant evidence indicates that SVR status results in fibrosis regression in a pre-transplant setting but in slower fibrosis progression in a post-transplant setting. The underlying mechanism of this differing behavior is unknown. Some evidence indicates that achieving SVR resulted in an increased risk of both acute and chronic rejection [21]. Whether this was truly the effect of the interferon remains unknown. Immunosuppressive therapy is well known to cause insulin resistance and is associated with non-alcoholic steatohepatitis (NASH). No studies, including ours, have looked into the features of NASH in follow up biopsies.

The pitfalls of our study are due to its retrospective nature, though the data was collected prospectively from a transplant database. The interval between biopsies was not uniform, and the follow-up interval was relatively short (1.5 years after the completion of treatment).

In conclusion, our study shows that achieving SVR with anti-HCV therapy in liver transplant recipients does not result in fibrosis regression. This is in contrast to some previously published data; however, SVR via anti-HCV therapy slows the progression of fibrosis over time, which translates into significant improvements in graft survival. Thus, all patients with recurrent $\mathrm{HCV}$ infection should be considered for treatment at an early recurrence stage.

\section{Grants}

None.

\section{Financial Support}

None.

\section{Conflict of Interest}

None.

\section{Abbreviations}

ALT: alanine aminotransferase; AST: aspartate transaminase; DAAs: direct acting antivirals; HCV: hepatitis $\mathrm{C}$ virus; LT: liver transplant; MELD: model for end-stage liver disease; MHAI: modified Ishak-Knodell activity index; NHBD: nonheart beating donor; NS: not significant; SD: standard deviation; SVR: sustained viral response

\section{References}

1. Forman LM, Lewis JD, Berlin JA, Feldman HI, Lucey MR. The association between hepatitis $\mathrm{C}$ infection and survival after orthotopic liver transplantation. Gastroenterology. 2002;122(4):889-896.

2. Prieto M, Berenguer M, Rayon JM, Cordoba J, Arguello L, Carrasco D, Garcia-Herola A, et al. High incidence of allograft cirrhosis in hepatitis $C$ virus genotype $1 \mathrm{~b}$ infection following transplantation: relationship with rejection episodes. Hepatology. 1999;29(1):250-256.

3. Schluger LK, Sheiner PA, Thung SN, Lau JY, Min A, Wolf DC, Fiel I, et al. Severe recurrent cholestatic hepatitis $\mathrm{C}$ following orthotopic liver transplantation. Hepatology. 1996;23(5):971-976.

4. Doughty AL, Spencer JD, Cossart YE, McCaughan GW. Cholestatic hepatitis after liver transplantation is associated with persistently high serum hepatitis C virus RNA levels. Liver Transpl Surg. 1998;4(1):15-21.

5. Shaikh O. Hepatitis C Virus Infection Following Liver Transplantation: Natural History and Treatment. In: Medscape Today;2007.

6. Wang CS, Ko HH, Yoshida EM, Marra CA, Richardson K. Interferon-based combination anti-viral therapy for hepatitis $\mathrm{C}$ virus after liver transplantation: a review and quantitative analysis. Am J Transplant. 2006;6(7):15861599.

7. Forns X, Fontant RJ, Moonka D, McHutchison J, Symonds W, Denning J. Initial evaluation of the sofosbuvir compassionate use program for patients with severe recurrent $\mathrm{HCV}$ following liver transplantation. Hepatology. 2013;58:Abstract-1084.

8. Price JC, Terrault NA. Treatment of hepatitis $\mathrm{C}$ in liver transplant patients: interferon out, direct antiviral combos in. Liver Transpl. 2015;21(4):423-434.

9. D'Ambrosio R, Aghemo A, Rumi MG, Ronchi G, Donato MF, Paradis V, Colombo M, et al. A morphometric and immunohistochemical study to assess the benefit of a sustained virological response in hepatitis $\mathrm{C}$ virus patients with cirrhosis. Hepatology. 2012;56(2):532-543.

10. Shiffman ML, Hofmann CM, Contos MJ, Luketic VA, Sanyal AJ, Sterling RK, Ferreira-Gonzalez A, et al. A randomized, controlled trial of maintenance interferon 
therapy for patients with chronic hepatitis $\mathrm{C}$ virus and persistent viremia. Gastroenterology. 1999;117(5):11641172.

11. Di Bisceglie AMS ML, Everson GT, Lindsay KL, Everhart JE, Wright EC, Lee WM. Prolonged Antiviral Therapy With PEGinterferon to Prevent Complications of Advanced Liver Disease Associated With Hepatitis C: Results of the Hepatitis C Antiviral Long-term Treatment against Cirrhosis (HALT-C) Trial. Hepatology. 2007;46:822A.

12. Belli LS, Volpes R, Graziadei I, Fagiuoli S, Starkel P, Burra P, Alberti AB, et al. Antiviral therapy and fibrosis progression in patients with mild-moderate hepatitis $\mathrm{C}$ recurrence after liver transplantation. A randomized controlled study. Dig Liver Dis. 2012;44(7):603-609.

13. Bizollon T, Pradat P, Mabrut JY, Radenne S, Ducerf C, Baulieux J, Souquet JC, et al. Histological benefit of retreatment by pegylated interferon alfa- $2 \mathrm{~b}$ and ribavirin in patients with recurrent hepatitis $\mathrm{C}$ virus infection posttransplantation. Am J Transplant. 2007;7(2):448-453.

14. Bahra M, Neumann UP, Jacob D, Langrehr JM, Berg T, Neuhaus R, Neuhaus P. Fibrosis progression in hepatitis $\mathrm{C}$ positive liver recipients after sustained virologic response to antiviral combination therapy (interferon-ribavirin therapy). Transplantation. 2007;83(3):351-353.

15. Tame M, Buonfiglioli F, Del Gaudio M, Lisotti A, Cecinato P, Colecchia A, Azzaroli F, et al. Long-term leukocyte natural alpha-interferon and ribavirin treatment in hepatitis $\mathrm{C}$ virus recurrence after liver transplantation. World J Gastroenterol. 2013;19(32):5278-5285.

16. Carrion JA, Navasa M, Garcia-Retortillo M, Garcia-Pagan JC, Crespo G, Bruguera M, Bosch J, et al. Efficacy of antiviral therapy on hepatitis $\mathrm{C}$ recurrence after liver transplantation: a randomized controlled study. Gastroenterology. 2007;132(5):1746-1756.

17. Oton E, Barcena R, Moreno-Planas JM, Cuervas-Mons V, Moreno-Zamora A, Barrios C, Garcia-Garzon S, et al. Hepatitis $\mathrm{C}$ recurrence after liver transplantation: Viral and histologic response to full-dose PEG-interferon and ribavirin. Am J Transplant. 2006;6(10):2348-2355.

18. Fernandez I, Meneu JC, Colina F, Garcia I, Munoz R, Castellano G, Fuertes A, et al. Clinical and histological efficacy of pegylated interferon and ribavirin therapy of recurrent hepatitis $\mathrm{C}$ after liver transplantation. Liver Transpl. 2006;12(12):1805-1812.

19. Berenguer M, Aguilera V, Prieto M, Ortiz C, Rodriguez M, Gentili F, Risalde B, et al. Worse recent efficacy of antiviral therapy in liver transplant recipients with recurrent hepatitis $\mathrm{C}$ : impact of donor age and baseline cirrhosis. Liver Transpl. 2009;15(7):738-746.

20. Abdelmalek MF, Firpi RJ, Soldevila-Pico C, Reed AI, Hemming AW, Liu C, Crawford JM, et al. Sustained viral response to interferon and ribavirin in liver transplant recipients with recurrent hepatitis C. Liver Transpl. 2004;10(2):199-207.

21. Stravitz RT, Shiffman ML, Sanyal AJ, Luketic VA, Sterling RK, Heuman DM, Ashworth A, et al. Effects of interferon treatment on liver histology and allograft rejection in patients with recurrent hepatitis $\mathrm{C}$ following liver transplantation. Liver Transpl. 2004;10(7):850-858.

22. Habib S, Chang CCH, De Vera M, Rana AA, Shaikh OS. Interferon treatment improves survival among liver transplant recipients with recurrent hepatitis C. J Surgery. 2013;1.

23. Garcia-Reyne A, Lumbreras C, Fernandez I, Colina F, Abradelo M, Magan P, San-Juan R, et al. Influence of antiviral therapy in the long-term outcome of recurrent hepatitis $\mathrm{C}$ virus infection following liver transplantation. Transpl Infect Dis. 2013;15(4):405-415.

24. Wawrzynowicz-Syczewska M, Zeair S, Andruszkiewicz A, Bartoszewicz K, Slawinski J, Laurans L, Jurczyk K, et al. Impact of antiviral treatment on survival in HCV-positive liver recipients. Ann Transplant. 2014;19:367-372.

25. Gane EJ. The natural history of recurrent hepatitis $\mathrm{C}$ and what influences this. Liver Transpl. 2008;14(Suppl 2):S36-44.

26. Berenguer M, Roche B, Aguilera V, Duclos-Vallee JC, Navarro L, Rubin A, Pons JA, et al. Efficacy of the retreatment of hepatitis $\mathrm{C}$ virus infections after liver transplantation: role of an aggressive approach. Liver Transpl. 2013;19(1):69-77.

27. Berenguer M. Systematic review of the treatment of established recurrent hepatitis $\mathrm{C}$ with pegylated interferon in combination with ribavirin. J Hepatol. 2008;49(2):274287.

28. Ishak K, Baptista A, Bianchi L, Callea F, De Groote J, Gudat F, Denk H, et al. Histological grading and staging of chronic hepatitis. J Hepatol. 1995;22(6):696-699.

29. Banff schema for grading liver allograft rejection: an international consensus document. Hepatology. 1997;25(3):658-663.

30. Shakil AO, Habib S, Berk B, Eghtesad B, Marcos A. A trial of PEGylated interferon and ribavirin among liver transplant recipients with hepatitis $\mathrm{C}$; reasons for screening failure and low enrollment. University of Pittsburg, Pittsburg, PA. Hepatology. 2004;40:360.

31. Rodriguez-Luna H, Khatib A, Sharma P, De Petris G, Williams JW, Ortiz J, Hansen K, et al. Treatment of recurrent hepatitis $\mathrm{C}$ infection after liver transplantation with combination of pegylated interferon alpha $2 \mathrm{~b}$ and ribavirin: an open-label series. Transplantation. 2004;77(2):190-194.

32. Neff GW, Montalbano M, O'Brien CB, Nishida S, Safdar $\mathrm{K}$, Bejarano PA, Khaled AS, et al. Treatment of established recurrent hepatitis $\mathrm{C}$ in liver-transplant recipients with pegylated interferon-alfa- $2 \mathrm{~b}$ and ribavirin therapy. Transplantation. 2004;78(9):1303-1307.

33. Dumortier J, Scoazec JY, Chevallier P, Boillot O. Treatment of recurrent hepatitis $\mathrm{C}$ after liver transplantation: a pilot study of peginterferon alfa- $2 \mathrm{~b}$ and ribavirin combination. J Hepatol. 2004;40(4):669-674.

34. Heydtmann M, Freshwater D, Dudley T, Lai V, Palmer S, Hubscher S, Mutimer D. Pegylated interferon alpha-2b for patients with HCV recurrence and graft fibrosis following liver transplantation. Am J Transplant. 2006;6(4):825833.

35. Castells L, Vargas V, Allende H, Bilbao I, Luis Lazaro J, Margarit C, Esteban R, et al. Combined treatment with pegylated interferon (alpha-2b) and ribavirin in the acute 
phase of hepatitis $\mathrm{C}$ virus recurrence after liver transplantation. J Hepatol. 2005;43(1):53-59.

36. Neumann U, Puhl G, Bahra M, Berg T, Langrehr JM, Neuhaus R, Neuhaus P. Treatment of patients with recurrent hepatitis $\mathrm{C}$ after liver transplantation with peginterferon alfa-2B plus ribavirin. Transplantation. 2006;82(1):43-47.

37. Chalasani N, Manzarbeitia C, Ferenci P, Vogel W, Fontana RJ, Voigt M, Riely C, et al. Peginterferon alfa-2a for hepatitis $\mathrm{C}$ after liver transplantation: two randomized, controlled trials. Hepatology. 2005;41(2):289-298.

38. Wells MM, Roth LS, Marotta P, Levstik M, Mason AL, Bain VG, Chandok N, et al. Increased duration of dual pegylated interferon and ribavirin therapy for genotype 1 hepatitis $\mathrm{C}$ post-liver transplantation increases sustained virologic response: a retrospective review. Saudi J Gastroenterol. 2013;19(5):223-229.

39. Berenguer M, Ferrell L, Watson J, Prieto M, Kim M, Rayon M, Cordoba J, et al. HCV-related fibrosis progression following liver transplantation: increase in recent years. J Hepatol. 2000;32(4):673-684.

40. Chen EY, Lee WM, Hynan LS, Singal AG. A survey of hepatitis $\mathrm{C}$ treatment clinical practice patterns using the newly approved protease inhibitors. J Clin Gastroenterol. 2013;47(9):800-806. 